\title{
Mavenness And Salespeople Success: An Empirical Investigation
}

Dale T. Eesley, Ph. D., University of Nebraska at Omaha, USA

Phani Tej Adidam, Ph. D., University of Nebraska at Omaha, USA

\begin{abstract}
The sales literature has examined many characteristics of highly successful salespeople but as yet has not evaluated the concept of mavenness in the context of sales. Mavens are persons who have a passionate desire to freely share their expertise and knowledge for the benefit of others. This paper develops a three-factor measure of mavenness that measures levels of expertise, passion and the desire to share knowledge, and tests if higher levels of mavenness are associated with superior salesperson performance. The scale was administered to a sample of 122 salespersons in a large insurance company. Data on salesperson performance as well as other control variables were collected from archival records. Confirmatory factor analysis provided satisfactory support for the scale. Mavenness and the control variables were regressed on salesperson performance. All three factors of mavenness were highly significant. Sales managers can improve the selection and training of their sales force by using the scale to find candidates with high levels of mavenness. Although the concept of mavenness is not new, no attempt to measure this trait has been made previously. Furthermore, this trait has not before been tested to see if high levels of mavenness are associated with superior salesperson performance.
\end{abstract}

Keywords: Salespeople traits; Mavenness; Expertise; Passion; Teaching; Sharing

\section{INTRODUCTION}

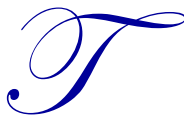

he importance of identifying individuals with the potential for high performance selling is a difficult task, and has been the focus of much of the sales literature. For example, qualities such as persuasiveness, the ability to network and years of experience may each contribute to the success of a salesperson. Screening for such traits helps companies reduce the significant costs of hiring and training salespersons. This is especially important in a position where 50\% of employees leave after the first year, and $80 \%$ leave in the next (Adidam and Srivastava, 2002). When less than adequate salespeople are hired, a firm not only suffers direct turnover related expenses such as wasted salaries and training, it may also diminish its reputation for quality and service and drive down company morale (Mayer \& Greenberg, 2006). While each advance in knowledge should simplify the search for quality salespeople, sales managers still spend large amounts of time attempting to recruit and hire quality salespeople (Adidam, 2006). Clearly, the need to develop more tools by which to identify high quality salespeople is important.

\section{MAVENNESS AND THE TRADITIONAL QUALITIES OF A GOOD SALESPERSON}

The list of traits and behaviors that enhance a salesperson's performance is long. Traits such as empathy, ego drive, integrity, high energy level, good self-image, desire to learn, relationship management and communication skills are clearly critical (Adidam, 2009; Kahle, 2007; Mayer \& Greenberg, 2006). Yet one trait that has not yet been applied in the sales field is the concept of mavenness. Mavenness is the passionate desire to freely share expertise knowledge for the benefit of others (Eesley \& Adidam, 2011). This is a trait commonly seen in mentors or educators, and is similar to Malcolm Gladwell's conceptualization of mavens as people who have high levels of expertise, social and communication skills, and an almost pathological desire to be helpful (Gladwell, 2002; p. 8). 
Mavens can be differentiated from other mentors, gurus or management consultants in at least three ways. First, mavens desire to share their knowledge. Therefore they seek out others rather than being solicited for assistance. Second, mavens freely offer their knowledge without a direct connection to remuneration from the recipient. Finally, mavenness is not compensated for by a company, but is instead expressed when the maven's behavior goes beyond the requirements of their employment and duties. Clearly, mavenness is a desirable quality in the context of sales, and a better understanding of the components of mavenness, which are expertise, passion and the desire to share knowledge, will be helpful for improving sales performance. While each of these qualities may contribute to a salesperson's success, the combination of these three creates a heightened capacity to effectively communicate and influence others. We will discuss each one briefly, and then consider their joint application.

\section{Expertise}

Expertise, and in particular, marketing expertise, developed over time, is a highly critical skill for companies, ranked second only to access to financial resources (Song, 2008). Individuals with greater expertise are better able to decode cues from clients and the environment, allowing them to better select who to contact and what direction to lead them in (Hatch, 2009). Additionally, expertise provides legitimacy and power to the salesperson (Fiol, O'Connor and Aguinis, 2001), better enabling them to influence potential clients. Individuals with experience-based knowledge increase their ability to generate solutions by focusing attention on customer information (Gaglio, 1997). Individuals who possess this quality are also likely to have a following of people who want to learn from their expertise because they consider them to be more trustworthy. Thus firms who hire mavens improve the leadership skills in their organization, improving employee morale, motivation, and organizational success.

Furthermore, expertise increases the ability to understand a wide range of information (Baron and Ensley, 2006), and such individuals are more likely to have an increased capacity to satisfy customer needs that are yet to be fulfilled (Westhead, Ucbasaran, and Wright, 2005). Salespeople who thus meet and exceed their customers' expectations develop tremendous credibility with customers. Customers will be willing to develop a relationship of trust, and thereby achieve high levels of satisfaction and commitment with the salesperson.

\section{Passion}

The second component of mavenness is passion. Passion is an "intense affective state accompanied by cognitive and behavioral manifestations of high personal value" (Chen, Yao, and Kotha, 2009). Accordingly, passion produces a strong affective connection that is apparent in the individual's enthusiasm, commitment, and readiness. Passion increases endurance in the face of difficulties (Locke, 2000) and heightens the ability to solve problems creatively (Cardon, et al., 2009). Passion increases communicated vision, goals, and self-efficacy (Baum and Locke, 2004). Passion increases emotional expressiveness, which has been associated with higher levels of business income and sales revenue (Baron and Markman, 2000, 2003), while high levels of positive affect led to greater persuasiveness and size of social networks (Baron, 2008). When salespeople are passionate about their products or services, it is highly likely that their enthusiasm will carry over into their sales presentations. Moreover, when combined with expertise, passion takes on an authenticity that increases its appeal to potential stakeholders. Thus, it is hypothesized that salespeople who exhibit passion during the sales process will be more likely to succeed than those who are unable to exhibit similar levels of passion.

\section{Desire to share knowledge for the benefit of others}

Individuals with high levels of mavenness voluntarily seek out opportunities to share their expertise. The extent to which they do this beyond reasonable expectations for monetary reward increases the trust and acceptance by potential customers and increases the likelihood of making a sale. Moreover, evidence of a strong desire to share knowledge enhances the maven's reputation and increases their ability to develop larger social networks (Baron and Tang, 2009). Mavens receive information from a wide base of customers because they are enthusiastic to reach out to any willing party. This aids the salesperson by developing a broader base of information and allows them to form more radical or innovative customer solutions (Marvel and Lumpkin, 2007; De Carolis, Litzky and Eddleston 2009; Ucbasaran, Westhead and Wright 2009). In addition, the interaction that comes from continually sharing their 
knowledge with others heightens their self-confidence and raises their self-efficacy regarding sales (Baum and Locke, 2004). As Bandura (1986) observed, self-efficacy is enhanced and sustained by reciprocal interaction that creates a virtuous cycle in which self-efficacy affects and is affected by behavior and environment. Thus salespeople with a high desire to share their knowledge maintain or increase their confidence to sell at a high level.

By combining the desire to teach for the benefit of others with expertise and passion, mavenness becomes a trait that is more than the sum of its first-order factors. Each is essential, but not sufficient, to express the construct of mavenness (Barney \& Mackey, 2005), and the removal of expertise, passion or the desire to teach would completely alter the meaning of mavenness (Jarvis, et al. 2003). While knowledge and passion have known effects on sales outcomes, when combined with the extroverted desire to share this knowledge, a complex series of interactions is initiated that creates a virtuous circle that expands the breadth of knowledge, relationship building, and the confidence needed for successful sales behavior.

Following the reasoning above, we theorize that individuals with high levels of mavenness will have greater success as salespersons. Specifically, we hypothesize that:

$\mathbf{H}_{1}$ : $\quad$ Expertise is positively related to a salesperson's success.

$\mathbf{H}_{2}$ : $\quad$ Passion (related to their products and services) is positively related to a salesperson's success.

$\mathbf{H}_{3}$ : $\quad$ Desire to share knowledge is positively related to a salesperson's success.

\section{RESEARCH METHODOLOGY}

\section{Setting and Sample}

This study is cross-sectional in nature because we are assessing the relationship between a salesperson's mavenness and his/her current success, as opposed to potential success. In other words, if we can establish that salespeople with high mavenness traits are also successful, then we could conduct a more comprehensive longitudinal study in which we could assess the mavenness traits during the selection process, and then track his/her success over the long term.

We conducted this study in a large insurance company that sells and markets life insurance products, among other things. We chose the insurance industry because this is one of the most competitive industries, with numerous choices available to consumers. Also, selling insurance policies, like any other intangible service, is much more intense than selling staple tangible products (Futrell, 2001).

Twenty five district sales managers were asked to evaluate two hundred salespeople via a questionnaire sent by their sales human resource department. The questionnaire contained questions related to their salespeople's traits of mavenness, as measured in the three-factor mavenness scale. As we were assessing current salespeople, as opposed to potential salespeople, we replaced the word "candidate" with "salesperson". The sales human resource department then aligned these responses with information of each salesperson's demographics (age and education level), overall professional sales experience, sales experience with this company, and sales person's success ratings. See Table 1 for the sample characteristics. A total of 122 questionnaires were used for this study, reflecting a $61 \%$ response rate. 
Table 1

Sample Characteristics

Insurance Salespeople $(\mathbf{n}=122)$

\begin{tabular}{lccccc}
\hline & Number & Percentage & Age & Number & Percentage \\
\hline Education Level & & & & under 25 & 11 \\
\hline High School & 15 & 12 & 26 to 35 & 28 & 9 \\
Undergraduate & 44 & 36 & 36 to 45 & 37 & 23 \\
Master's or more & 63 & 52 & 46 to 55 & 33 & 30 \\
& & & above 56 & 13 & 27 \\
& & & & & 11
\end{tabular}

\section{Overall sales experience}

\begin{tabular}{lllcll}
\multicolumn{5}{c}{ company } \\
\hline 2 to 6 years & 17 & 14 & 2 to 6 years & 25 & 20 \\
7 to 15 years & 44 & 36 & 7 to 15 years & 49 & 40 \\
16 to 25 years & 45 & 37 & 16 to 25 years & 35 & 29 \\
over 25 years & 16 & 13 & over 25 years & 13 & 11
\end{tabular}

Sales Success Index

(1.00 to 5.00)

\begin{tabular}{lll}
\hline below 2.50 & 22 & 18 \\
$2.51-3.50$ & 27 & 22 \\
$3.51-4.50$ & 50 & 41 \\
above 4.51 & 23 & 19 \\
\hline
\end{tabular}

In order to eliminate recent-performance bias, each salesperson's success rating, which is a multidimensional index, was measured as an average of the previous five performance evaluation cycles. Also, in order to eliminate any halo effects or sales performance bias, sales managers were not given any information regarding the background of this scale, as well as the reasoning behind this survey. Moreover, this was conducted separately from their regular performance evaluation cycle.

\section{Measures}

To test the effect of mavenness on salesperson performance, we developed and tested a scale to measure mavenness. In order to develop this scale, the components of mavenness were broken down into measurable qualities. We refer to this scale as the "Three-Factor Mavenness Scale." This scale has three components that can be measured using a seven-point rating scale ranging from "Strongly Disagree" (1) to "Strongly Agree" (7).

First, we focused on the component one - expertise in a given area or subject. After interviewing a candidate, the sales manager can rate his or her level of expertise in the subject at hand on a scale of 1 to 7,1 being novice and 7 being world class. This may be difficult to judge, but if the sales manager asks the right questions during the interview, he or she should get an idea on the candidate's expertise level in each area of the job, which can be averaged for a total expertise score. For example, if the job is selling mutual fund products, the sales manager should ask specific questions about the candidate's knowledge of the stock market, individual stocks, mutual fund companies, performance of the mutual funds over a given time period, tax laws related to investments in mutual funds, etc. Throughout the interview, the sales manager can score the candidate's level of knowledge in each area from 1 to 7; the scores can then be weighted appropriately then averaged for a total score in component one. We developed the following questions to evaluate expertise:

- $\quad$ Expertise

$\circ \quad$ The candidate is an expert in the field

- The candidate has specialized knowledge in the given subject area

- The candidate participates in ongoing activities to keep up his or her knowledge in the given subject area 
Next, we developed a scale for the second component of mavenness - passion or enthusiasm about the subject. This component is more subjective than component one, but again, it can be measured by asking the right interview questions. There are different ways to go about this, but one option is to ask the candidate how he or she feels about competing products. Using the example from above, the sales manager could ask what the candidate's opinion is on day trading stocks versus owning shares in mutual funds. A candidate who is passionate about mutual funds would have a very persuasive argument about why mutual funds are the best investment tool. This example also gives the sales manager insight into how the candidate would handle such questions in the sales field. The sales manager could then go further and ask how the candidate feels about the particular company's mutual funds versus competitors. Each situation will call for questions related to the specific job. Again, each question should be scored real time, then weighted and averaged after the interview to show a total score for component two. To measure passion, we used the following questions:

- $\quad$ Passion and Enthusiasm

$\circ \quad$ The candidate is excited about the given subject area

$\circ$ The candidate shows enthusiasm for the given subject area openly

- The candidate expresses enthusiasm for the given subject area in such a manner that others would be interested in learning more

Finally, we developed questions for the third component of mavenness - desire to share the knowledge one possesses with others. This component is probably the most subjective of them all, and hardest to judge. Much of it is similar to traditional characteristics of a good salesperson. It really comes down to leadership, and the candidate's desire to be a leader by sharing his or her knowledge and convincing others of his or her position. When interviewing a candidate, a sales manager should score him or her on the using the questions we propose below:

- $\quad$ Desire to Share Knowledge with Others

- The candidate shows a desire to inform others about what he or she knows

- The candidate is capable of clearly explaining the message he or she is delivering

$\circ$ The candidate is anxious to tell others about the latest and greatest news regarding the given subject area

All of these characteristics can be indicators for good leadership skills, which in turn signify a person who is willing and excited about spreading the word of his or her knowledge. Each of the scores above should be weighted and averaged, as done with components one and two.

\section{EMPIRICAL RESULTS}

\section{Measurement Model}

The performance of three reflective measures (expertise, passion, and desire to share) was assessed using coefficient alpha and confirmatory factor analysis. As shown in Table 2, internal consistency of the three reflective measures is satisfactory-lowest coefficient alpha is 0.74 for the passion construct. Also shown in the table are factor loadings from confirmatory factor analysis using LISREL 8.2 (Jöreskog and Sörbom, 1993). All paths are significant $(\mathrm{p}<.05)$, and in general, model fit is adequate (adjusted goodness-of-fit index [AGFI] $=.85$; root mean residual $[R M R]=.06)$. No items were deleted. Items in each construct were averaged to create a single indicator. Table 3 shows the correlation matrix of the key measures, along with their mean and standard deviation. 
Table 2

Unidimensionality and Internal Consistency of Three Reflective Constructs of Mavenness Scale Item

\begin{tabular}{lr}
\hline Expertise $(\boldsymbol{\alpha}=\mathbf{8 1})$ & 0.79 \\
\hline The salesperson is an expert in the field & 0.88 \\
The salesperson has specialized knowledge in the insurance industry & 0.92 \\
The salesperson participates in ongoing activities to keep up his or her
\end{tabular}

knowledge in the insurance industry

Passion and Enthusiasm $(\alpha=.74)$

$\begin{array}{ll}\text { The salesperson is excited about the insurance industry } & 0.69\end{array}$

$\begin{array}{ll}\text { The salesperson shows enthusiasm for the insurance products openly } & 0.58\end{array}$

The salesperson expresses enthusiasm for the insurance products in such a 0.73

manner that others would be interested in learning more

Desire to Share Knowledge with Others $(\alpha=.86)$

The salesperson shows a desire to inform others about what he or she knows

The salesperson is capable of clearly explaining the message he or she is

0.79

delivering

The salesperson is anxious to tell others about the latest and greatest news

0.79 regarding the insurance industry

Note: All paths significant $(\mathrm{p}<.05) \cdot \chi_{(152)}^{2}=243.69(\mathrm{p}=.00), \mathrm{GFI}=.88, \mathrm{AGFI}=.85, \mathrm{RMR}=.06$

Table 3

Correlation matrix

\begin{tabular}{lcccccc}
\hline & E & P & D & EL & Exp & SS \\
\hline Expertise & 1.00 & & & & & \\
Passion & 0.54 & 1.00 & & & & \\
Desire to Share & 0.39 & 0.35 & 1.00 & & & \\
Education Level & 0.43 & 0.30 & 0.26 & 1.00 & & \\
Experience & 0.40 & 0.24 & 0.12 & 0.22 & 0.10 & \\
Sales Success & 0.26 & 0.23 & 0.27 & & & \\
& & & & & & \\
Mean & 3.94 & 3.68 & 3.81 & 2.39 & 2.56 & 3.14 \\
Standard Deviation & 0.77 & 0.69 & 0.76 & 0.86 & 0.44 & 0.73 \\
\hline
\end{tabular}

\section{Regression analysis}

In order to empirically corroborate the three hypotheses, regression analysis (OLS) was conducted. Salesperson's success was the dependent variable. In addition to the three predictor variables of mavenness (expertise, passion, desire to share), we also used four control variables of age, education level, salesperson's overall professional sales experience, and salesperson's experience with this company. Table 4 reports the standardized coefficients from the regression analyses. Model 1 contains only control variables. Due to the tremendous correlation between the three control variables of age, salesperson's overall professional sales experience, and salesperson's experience with this company, we created a weighted index called experience. Model 2 contains education level and experience. Model 3 is a full model. All models are statistically significant to at least $\mathrm{p}<.05$ or better. 
Table 4

Regression Results ${ }^{\mathbf{a}}$ : Salesperson's Success ${ }^{\mathrm{b}}$

\begin{tabular}{|c|c|c|c|}
\hline & & Model & \\
\hline Independent Variable & $(\mathbf{1})$ & (2) & (3) \\
\hline Expertise & & & $0.16 * * *$ \\
\hline Passion & & & $0.12 * *$ \\
\hline Desire to Share & & & $0.15 * * *$ \\
\hline Education Level & $0.16^{* *}$ & $0.14 * *$ & $0.10 * *$ \\
\hline Age & 0.04 & & \\
\hline Overall Sales Experience & $0.13 * *$ & & \\
\hline Sales Experience with Company & $0.08 *$ & & \\
\hline Experience & & $0.18 * * *$ & $0.19 * * *$ \\
\hline R-Squared & 0.12 & 0.15 & 0.21 \\
\hline Model F & $5.10 * *$ & $3.92 * * *$ & $4.83 * * *$ \\
\hline
\end{tabular}

${ }^{\mathrm{a}}$ Standardized regression coefficients $(\mathrm{n}=122)$.

bSalesperson's success is a multi-dimensional index average of previous five performance evaluations.

$* \mathrm{p}<0.10$

$* * \mathrm{p}<0.05$

$* * * \mathrm{p}<0.01$

Model 3 provides overwhelming support for all three hypotheses. As these are standardized coefficients, it is not surprising that expertise provides the strongest relationship with salesperson's success. Desire to share knowledge and ideas with others is a close second, while passion is third on the mavenness scale. Extant literature does not provide any basis regarding any hierarchy of these three constructs of mavenness. While it is interesting to see this hierarchy in our sample, we do not claim that this might be reflective of the population of salespeople.

\section{DISCUSSION}

The results indicate that each component of the mavenness scale - having expertise, passion, and a desire to share knowledge with others - is strongly associated with salesperson success. From the evidence afforded by this study, mavens are superior salespersons, not only because of the superior content of their sales pitch, but also their delivery of it. As salespeople, mavens are convincing representatives whose passion is persuasive and undergirded with the authenticity that comes from expertise (Cardon et al. 2009). Mavens mirror Miner's "empathetic supersalesmen" (1996, 2000), who want to assist their customers in any way possible. Miner (1996, 2000) observed that displays of empathy motivate the customer to return the favor by buying the product or service offered. More recently, this point has been supported by the popular business press, such as Gary Vaynerchuk's “ThankYou Economy" (2011) which posits that individuals that not only supply superior service, but put in more than required efforts, yield higher levels of sales than companies that do not.

Additionally, the construct of mavenness is useful because it provides a simple method to identify and nurture a key trait of successful salespeople. New salespersons can be advised to recognize those areas where their interests are strongest and to pursue education or training to increase their expertise in these areas. Offering inhouse training, business seminars, or allowing the individual to take related college classes can supercharge the salesperson's expertise. Passion can be enhanced by first identifying those areas that hold the most interest for the salesperson and then empowering them to pursue them. Identifying individuals that have a strong interest in the product or service being offered, or who feel strongly that what they offer the customer is highly beneficial will improve their sales capability. Similarly, the desire to share knowledge for the benefit of others can be increased by encouraging budding salespersons to begin sharing their expertise at the earliest stages of their career. By doing so, they can start to develop large and useful social networks, find areas of interest they had yet to discover, build strong communication skills, and perhaps most importantly, through the response and feedback of their audience, can develop a stronger sense of confidence in their sales capability. 
Sales managers can also improve the performance of their sales force by identifying individuals who tend to have higher levels of mavenness than other candidates. By including the questions from the three factor mavenness scale in the interview process, sales managers can improve their chances of hiring salespeople who will not only perform at higher levels, but positively impact the culture and reputation of the organization. In particular, the desire to share expert knowledge with others gives evidence of strong intrinsic motivation, which for salespeople is associated with being focused on sales mastery and creativity in their sales approach (Weitz and Sujan 1986).

Finally, for mavenness to have an impact in an organization, management will need to adopt a welcoming attitude toward maven behavior in the workplace. Because mavens passionately desire to freely share their knowledge for the benefit of others, they may often engage in activities that are not directly tied to closing a sale. Instead, management needs to understand how maven behaviors benefit the customer relationship, firm reputation, and long-term sales prospects for the firm. Managers of mavens need to view their salespeople not as source of costs and problems, but as assets that support the continuing survival and success of the organization (Sirota, Mischkind, and Meltzer, 2005, p 35).

\section{LIMITATIONS AND FUTURE RESEARCH}

In this study we have found evidence that salespeople with higher levels of mavenness do find greater levels of success. However, the primary limitation of this study is that the sample of salespeople is relatively small, cross-sectional and conducted at only one company. To be established then, is whether potential salespeople with higher levels of mavenness will in fact become high performing salespersons. To accomplish this, future research will need to incorporate larger and multi-site samples in a longitudinal study. Nevertheless, because our study collected measures of performance and other control variables from archival sources separate from the measure of mavenness, and that strength of the relationship was great, we have hope that these preliminary findings will generalize to the larger population.

While our findings in this sample were encouraging, there are many unanswered questions in regard to how the concept of mavenness can be used to develop superior salespeople. First, it is useful to examine in what sales context mavenness may be of most help. For example, is mavenness more useful in consumer sales or business to business sales? Is it more helpful in service or manufacturing industries? Is mavenness a greater asset in stable or uncertain environments? Is mavenness more useful in early or late stages of the sales process? Secondly, how should sales managers use mavenness in selecting and training their sales force? What level of mavenness is acceptable, and what steps are most helpful in building mavenness in existing salespeople? Finally, in what other contexts is mavenness a particularly useful trait to identify in individuals? Does the special skill set of mavens offer significant benefits when applied to other contexts such as new venture creation, social entrepreneurship, education, or politics?

\section{CONCLUSIONS}

Mavenness is a highly desirable quality that, until now, has received little attention in the sales literature; however, it appears to be a quality that should not be overlooked. Mavenness is a highly useful concept for sales managers because it is associated with successful selling and can be easily identified, measured, and enhanced. When looking for potential sales candidates, sales managers can use our three-factor scale of mavenness to quantify the level of this quality each candidate possesses. This will help them more easily compare one candidate to another. In addition to scouting new salespeople, sales managers can and should foster greater levels of mavenness in their existing sales force. Mavenness could be the key sales managers have been looking for to identify and sustain a high performing sales force.

\section{ACKNOWLEDGEMENTS}

The authors appreciate the Office of Sponsored Projects, University of Nebraska at Omaha, Omaha, NE. 


\section{AUTHOR INFORMATION}

Dr. Dale Eesley is the Director of the Center for Innovation, Entrepreneurship and Franchising at the University of Nebraska at Omaha. He received his Ph. D. in Strategy from University of Wisconsin -Madison. His research interests are in Entrepreneurship, Strategy, and Creativity. E-mail: deesley@ unomaha.edu

Dr. Phani Tej Adidam is the Executive Education Professor of Business Administration at the University of Nebraska at Omaha. He received his Ph. D. in Marketing from Texas Tech University. His research interests are in Marketing Strategy, Competitive Intelligence, Sales Management, and Decision making. He has published in Journal of Marketing, Journal of Applied Business Research, Journal of Business and Industrial Marketing, Journal of Marketing Theory and Practice, Marketing Management Journal, and Marketing Intelligence and Planning, among others. E-mail: padidam@unomaha.edu (Corresponding author)

\section{REFERENCES}

1. Adidam, P.T. (2009), "Mavenness: A Non-Explored Trait of Quality Salespeople," Paradigm: A Research Journal, Vol. 13 No. 1, pp. 6-10.

2. Adidam, P.T. (2006), "Causes and Consequences of High Turnover by Sales Professionals," Journal of American Academy of Business, Vol. 10 No. 1, pp. 137-141.

3. Adidam, P.T., and Srivastava, R. (2002), "Building a Strategic Advantage: Fostering Optimism within a Salesforce," Marketing Management Journal, Vol. 11, No. 2, pp. 12-23.

4. Bandura, A. (1986), Social Foundations of Thought and Action: A Social Cognitive Theory, Prentice-Hall, Englewood Cliffs, NJ.

5. Barney, J. B., and T. B. Mackey (2005), "Testing Resource-Based Theory," in Research Methodology in Strategy and Management. Eds. D. Ketchen, and D. D. Bergh. Amsterdam: Elsevier, pp. 1-13.

6. Baron, R. A. (2008), "The Role of Affect in the Entrepreneurial Process," Academy of Management Review, Vol. 33 No. 2, pp. 328-340.

7. Baron, R. A., and M. D. Ensley (2006), "Opportunity Recognition as the Detection of Meaningful Patterns: Evidence from Comparisons of Novice and Experienced Entrepreneurs," Management Science, Vol. 52 No. 9, pp. 1331-1344.

8. Baron, R. A., and G. D. Markman (2003), "Beyond Social Capital: The Role of Entrepreneurs' Social Competence in Their Financial Success," Journal of Business Venturing Vol. 18 No. 1, pp. 41-60.

9. Baron, R. A., and G. D. Markman (2000), "Beyond Social Capital: How Social Skills Can Enhance Entrepreneurs' Success," Academy of Management Executive, Vol. 14 No. 1, pp. 106-116.

10. Baron, R. A., and J. Tang (2009), "Entrepreneurs' Social Skills and New Venture Performance: Mediating Mechanisms and Cultural Generality," Journal of Management Vol. 35 No. 2, pp. 282-306.

11. Baum, J. R., and E. A. Locke (2004), "The Relationship of Entrepreneurial Traits, Skill, and Motivation to Subsequent Venture Growth," Journal of Applied Psychology Vol. 89 No. 4, pp. 587-598.

12. Cardon, M. S., J. Wincent, J. Singh, and M. Drnovsek (2009), "The Nature and Experience of Entrepreneurial Passion," Academy of Management Review, Vol. 34 No. 3, pp. 511-532.

13. Chen, X., X. Yao, and S. Kotha (2009), "Entrepreneur Passion and Preparedness in Business Plan Presentations: A Persuasion Analysis of Venture Capitalists' Funding Decisions," Academy of Management Journal, Vol. 52 No. 1, pp. 199-214.

14. De Carolis, D., B. E. Litzky, and K. Eddleston (2009), "Why Networks Enhance the Progress of New Venture Creation: The Influence of Social Capital and Cognition," Entrepreneurship: Theory \& Practice, Vol. 33 No. 2, pp. 527-545.

15. Futrell, C. M. (2001), Sales Management Teamwork, Leadership, and Technology, 6th ed., South-Western, Cincinnati, $\mathrm{OH}$.

16. Eesley, D.T, and P. T. Adidam (2011), "Mavenness \& Entrepreneurship: The Passionate Desire to Share Expertise and its Impact on New Venture Creation," Business Journal for Entrepreneurs, 3, 14-20.

17. Fiol, C. M., E. J. O'Connor, and H. Aguinis (2001), "All for One and One for All? The Development and Transfer of Power Across Organization Levels," Academy of Management Review, Vol. 26 No. 2, pp. 224242 . 
18. Gaglio, C. (1997), "Opportunity Identification: Review, Critique and Suggested Research Directions," in Advances in Entrepreneurship, Firm Emergence and Growth. Ed. J. A. Katz. Greenwich, CT: JAI Press, pp. 139-202.

19. Gladwell, M. (2002), The Tipping Point: How Little Things Can Make a Big Difference, Back Bay Books, Boston, MA.

20. Hatch, M. (1997), "Jazzing Up the Theory of Organizational Improvisation," Advances in Strategic Management, Vol. 14, pp. 181-191.

21. Jarvis, C. B., S. B. Mackenzie, P. M. Podsakoff, D. G. Mick, and W. O. Bearden (2003), "A Critical Review of Construct Indicators and Measurement Model Misspecification in Marketing and Consumer Research," Journal of Consumer Research, Vol. 30 No. 2, pp. 199-218.

22. Jöreskog, K. G., \& Sörbom, D. (1993), LISREL 8, Scientific Software Inc., Chicago.

23. Kahle, D. (2007) "How to Spot a Potential Star Salesperson: Six Qualities of Superstar Salespeople," Presentation-Pointers. Available http://www.presentation-pointers.com/showarticle/articleid/558/, accessed February 2012.

24. Locke, E. A. (2000), The Prime Movers, Amacom, New York.

25. Marvel, M. R., and G. Lumpkin (2007), "Technology Entrepreneurs' Human Capital and its Effects on Innovation Radicalness," Entrepreneurship: Theory \& Practice, Vol. 31 No. 6, pp. 807-828.

26. Mayer, D., \& Greenberg, H. (2006) "What Makes A Good Salesman?" Harvard Business Review, Vol. 84 No. 7/8, pp. 164-171.

27. Miner, J. (2000), "Testing a Psychological Typology of Entrepreneurship Using Business Founders," Journal of Applied Behavioral Science, Vol. 36 No. 1, pp. 43-69.

28. Miner, J. (1996), "Evidence for the Existence of a Set of Personality Types, Defined by Psychological Tests, that Predict Entrepreneurial Success," Frontiers of Entrepreneurship Research, Vol. 16, pp. 62-76.

29. Sirota, D., Mischkind, LA and Meltzer, MI (2005) The Enthusiastic Employee - How Companies Profit by Giving Workers What They Want. Wharton School Publishing, Philadelphia, PA.

30. Song, M., K. Podoynitsyna, H. van der Bij, and J. I. M. Halman (2008), "Success Factors in New Ventures: A Meta-Analysis," Journal of Product Innovation Management, Vol. 25 No. 1, pp. 7-27.

31. Ucbasaran, D., P. Westhead, and M. Wright (2009), "The Extent and Nature of Opportunity Identification by Experienced Entrepreneurs," Journal of Business Venturing, Vol. 24 No. 2, pp. 99-115.

32. Vaynerchuk, Gary (2011), The Thank You Economy. New York: Harper Business.

33. Weitz, B. A., H. Sujan, and M. Sujan (1986), "Knowledge, Motivation, and Adaptive Behavior: A Framework for Improving Selling Effectiveness," Journal of Marketing, Vol. 50 No. 4, pp. 174-191.

34. Westhead, P., D. Ucbasaran, and M. Wright (2005), "Experience and Cognition," International Small Business Journal, Vol. 23 No. 1, pp. 72-98. 